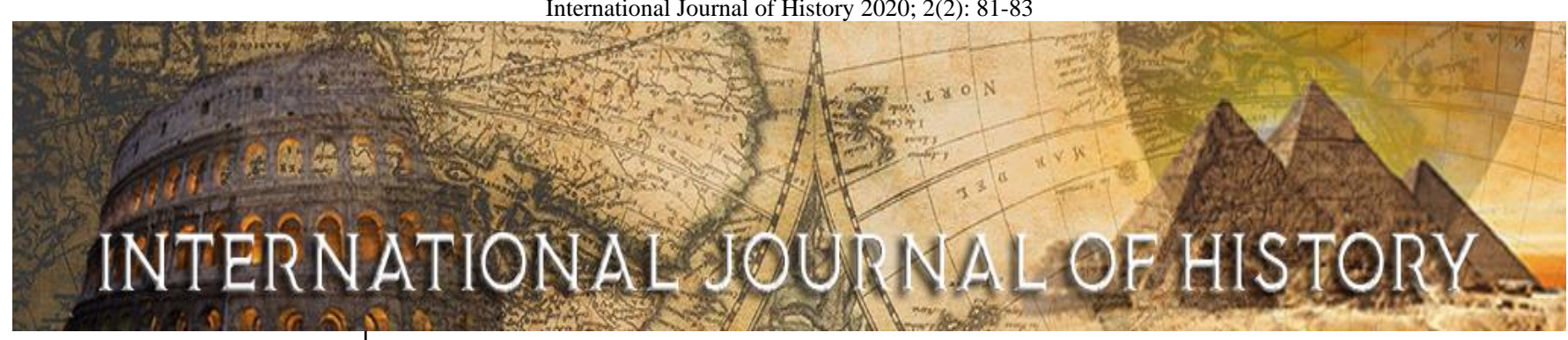

E-ISSN: 2706-9117 P-ISSN: 2706-9109 IJH 2020; 2(2): 81-83 Received: 28-06-2020 Accepted: 30-07-2020

Dr. Swati Kumari P.S.- L.N.M.U. Campus Dist- Darbhanga, Bihar, India
Corresponding Author: Dr. Swati Kumari P.S.- L.N.M.U. Campus Dist- Darbhanga, Bihar, India

\section{Topic - Mythological concepts of pre vedic Mithila in migration}

\section{Dr. Swati Kumari}

DOI: $\underline{\text { https://doi.org/10.22271/27069109.2020.v2.i2b.48 }}$

\begin{abstract}
Evetually the aboriginals attracted by the settled life of these vedic immigrants drew nearer to them and started co-operating with them participation in their agricultural operations and Ultimately were so to say, absorbed in the lowest rung to their society. It presented a contrast to the panorama of religious and philosophical thought of greater Mithila. The period discussed so far as we the immigration of many people into Mithila. The videha, Licchani vajji and a host of other Aryan as well as non-Aryan tribes entered in succession the virgin land of Mithila and settled there comfortable. Perhaps granting of land free of such king in Mithila.
\end{abstract}

Keywords: Mithila, agriculture, immigrants, migrate, migration, Magadha, power

\section{Introduction}

Pre-vedic Mithila was inhabited by a number of tribes belonging to two groups. The Kiratas in the north and the Kolas in the south. They dwelt in forest and marshy land and lived on hunting and fishing. Near about 1500-1600bc. One Videghamathab. With a host of his learned priests and followers crossed the river Sadanira (Modem Gandak) from the west and established his kingdom in Mithila ${ }^{[1]}$. These vedic people new agriculture and cattle rearing and possessed a high standard of rural civilization and culture. The descendants of the king videgha (videha) ruled Mithila for a long time. The epics and the puranas ${ }^{[2]}$, have listen the names of more than forty kings. All these kings were referred to as Maithila ${ }^{[3]}$ or vaideha.

Evetually the aboriginals attracted by the settled life of these vedic immigrants drew nearer to them and started co-operating with them participation in their agricultural operations and Ultimately were so to say, absorbed in the lowest rung to their society. The confluence of these varied elements in the society gave birth to what we call the composite culture of Mithila.

Some of the puranas reveal another settlement of the Aryan people existing simultaneously in the southern part of Mithila. One of the rulers of the settlement was called visala and his capital was called visala or vaisali which in now a famous Buddhist site. But the puranas are silent about the later generations. It is generally held that probably the vaisali dynasty was founded in cir. 2,410 B.C. and end in cir. 1,900B.C. Afterwards the territory of vaisali was annexed to the kingdom of the videhas. The dynasty of videha is said to have ended as a result of a revolt of the subjects against the oppression of the last king karals Janaka ${ }^{[4]}$ in about the $7^{\text {th }}$ or the $6^{\text {th }}$ century B.C according to some puranic chronologists.

Then comes a totally different milieu: different people, politics, religion and thought revealed in quite different literary (and archaeological) sources. After the decline and fall of monarchy in Mithila, a number of republican states emerged. Eventually sometimes before the birth of Gautama Buddha these states formed a federation called Vajji-mahasangha. It consisted, of eight organised clans, viz.. videha. Licchavi, Inatraka, vajji, Ugra, Bhoga, Aiksvaka and karuva Most problbly they were later immigrants. Unlike the earlier videhas. the were traders and merchants mainly interested in their business and the least concerned with religion and philosophy.

After the advent of Vardhamana Mahavira and Gautama Buddha on the scene vaisali rose to an immense height as a centre of Jinisms ${ }^{[5]}$ and Buddhism. It presented a contrast to the panorama of religious and philosophical thought of greater Mithila. Naturally in ideological and philosophical clash took place between the orthodox Brahmanas in the north and the 
reformists in the south. This clash laid the foundation of the future development of a sound and scientific system of debate i.e. logic. The federal republic of vaisali lost its independence at the hands of the imperial forces of Ajatasatru (516-489B.C.) ${ }^{[6]}$ who proudly called himself vaidehi- putra. Thus the federation ended in about 446 B.C. but is constituents especially the Licchavi Sangha survived for a pretty long time under the suzerainty of the Magadhan emperors. It existed as late as the beginning of the $5^{\text {th }}$ century a.d. as we find Samudragupta (33-380) referring to himself as Picchavi-dauhitra "Son of the daughter of Licchavi". The famous Sanskrit poet and dramatist Kalidasa mentions Mithila as an important region ${ }^{[7]}$ When in 635 a.d. Hiuen Tsang visited vaisali, he found it dilapidated and ruined, and the supremacy of Brahmanism revived. The period discussed so far as we the immigration of many people into Mithila: the videha, Licchani vajji and a host of other Aryan as well as non-Aryan tribes entered in succession the virgin land of Mithila and settled there comfortable. The only instance of emigration from Mthila during this period was the establishment of a colony in the southern part of china especially in Yunnan, where some towns and head quarters were named Mithila and Videha ${ }^{[8]}$. While there were thus brisk political and religious activities in the south, we do not know what happened to the orthodox school in the north. Perhaps the whole of Mithila from the Ganga to the Himalayan region was under the sway of the vaisali power. But the intelligentsia, one may imagine, would have been watching anxiously the events and trends in the south and preparing themselves for confronting the same on the intellectual and cultural fronts. Their efforts were rewarded: voluminous literary works were produced on rituals, law, and philosophy such as the smrtis, dharmasutras, srautasutras, grhyasutras, nyayasutras, etc.

It is curious to note that after the mythical king Karala Janaka till the end of the republican states,one or the other types of local self government existed throught Mithila. There was perhaps no trace of kindship anywere. Thanks to the peace-loving, law-abiding and god-fearing nature of the people of Mithila, they could live happily even without any royal protection. Learned man and well-to do elders in their respective parishes did every thing that was expected of the kings. The panditas decided the course to be followed by the individuals and the society and the elder enforced their decision. The state of affairs reminds us of the utopia described in the Mahabgharata ${ }^{[9]}$. There was on kingdom, no king, on police, and on crime. Every one in the society protected the other mutually by righteous conduct. thus, there was no anarchy depsite the absence of monarchy.

But the powers that emerged outside did not spare Mithila to live along. Right from Ajataratru (516-499B.C.) of Magadha upto Ramapala (1077-1220 a.d.) of Bengal several rulers are said to have imposed their suzerainty upon Mithila ${ }^{[10]}$ The land fall under the sway of such power time to time. Ajatsatru (516-489) conquered vaisali and annexed Mithila to the Magadhan empire. One of his descendants namely Sisunga built his royal palace at vaisali, which continued to be the second capital of the Magadhan king till the advent of the Nanda. All the rulers who embraced Buddhism had a special fascination for vaisali. The Mauryas, the Sungas, the Kusanas, the Guptas, the Maukharis ${ }^{[11]}$ and others ruled Mithla successively, However, few of them left any impact on the life of the people outside vaisali.

The history of Mithila or Tirhut in the period under review is the history of constant warefare and invasions from outside, which led only to a chaotic situation The land suffered the pangs of the birth as well as the death of successive powers. perhaps every politically ambition ruler involved trode the land of Mithila in the course of his campaign for extending his kingdom to the foot-hills of the Himalayas.

Even after the end of the age of imperialism with the demise of Harsavardhan. Mithila continued to trodden by the Tibetans. later by the palas, Gurjara-Pratiharas, Rastrakutas and the condelas ${ }^{[12]}$. In the face of rapidly changing political scene, the pales ruled Mithila for the longest period and left their impact on the life and culture of the society to some extent. The Bhagalpur grand, Bangaon C.P. and the Naulagarh inscription fell us that Tirbhukti was one of the important administrative centres during the palarule ${ }^{[13]}$.

The period from the early 8th century to the beginning of the $11^{\text {th }}$ century A.D. in the history of Mithila can aptly be termed as the period of instability and turbulence. It proved to be the hunting or grazing ground for the political powers growing all around. The invaders intruded on the green pasture and left for good. The sons of the soil were neither interested nor affected by these political vicissitudes. Even the elite and intelligentsia of the society were indifferent, the former busy with amassing wealth through all means, fair of foul and the latter living in watertight compartment of religion, philosophy and literature. Fequent floods, famines, overtaiation, unending indebtendness and all kinds of expoilation by the rulers made the life of the masses extermely miserable. No one rose to take cudgels against the oppressors. The traditional Hundu belief in the enmity between goddess of wealth and the goddess of learning was becoming a reality.

The panditas in general lived from hand to mouth But they knew how to conceal their poverty in the mane of simplicity and idealism. Unlike the other parts of India, land-grants or Jagirs were not available to the panditas during this period. It came into vogue only after Nanyadeva established himself as a sovereign kind if Mithila after defeating Ramapala. ${ }^{14}$ Perhaps granting of land free of such king in Mithila. It was ruled only by deputies or Governors who had no right to grant land free of revenue. No wonder no land grant of this period has been found. Indeed, the Mithila pandits and brahmanas by and large belonged to the landless class. The beginning of the $2^{\text {nd }}$ millenium a.d. is a landmark in the history of Mithila. Some of the most conspicuous features of the ear area as follows:

- Barring the mythological period for the first time in its history Mithila had a king on its own land.

- The kingship ushered in a kind of political and social traqulity.

- Under the patronge of kings and chieftains, all the branches of learning advanced appreciably.

- The Brahmanas and the kayasthas started to speciy their family affinity with the names of their original native village plus the name of the recent one known as the (Multi and Grama) respectively. This family-name, generally prefixed to the proper names facilitated the identification of the person referred to and served also as a proof of being a Maithila.

- A number of surnames denoting family affinity started to be appended to proper names such as Jha ${ }^{[15]}$, Mishra ${ }^{[16]}$, Thakura ${ }^{[17]}$, etc.

- The dating of manuscripts and documents in terms of 
the Saka era came in vogue.

- The migration of the Maithil people of different disciplines increased repidly.

- The Brahnanas, the kayasthas and to some extent the other castes of Mithila confined their marital relations to their own castes of Mithila and thus distinct communities of Maithila Brahmanas and kayasthas were carved out.

- After the and of the vajjmahasangha till the advent of the Karnatas the political history of Mithila was the history of constant invasions, defeats and subjugations in the series was a Karnata Ksatriya Nanyadeva who, unlike the previous ones, entered the country with little resistance. made his capital in the heart of Mithila, gained the confidence of the people naturalized himself in the true sense. proudly acclaimed himself as Mithilesa, firmly and powerfully established as a monarch, and started to rule Mithila in peace and prosperity.

\section{Reference}

1. Satapatha Brahamana, 1,3-3,11-20.

2. Vrihad Vishnupurana, Srimad-Bhagavata and Valmiki Ramayana Mithila Mahatmayakhand, Addition, Darbhanga, 5-8.

3. Idid, 14 .

4. Shamashastri, Arthasastra of kautilya, 1, VI, 6-7.

5. Sinha BP. The Comprehensive History of Bihar, Patna, 1974; I(I):104.

6. Yogendera Mishra, An Early History of vaisali, Delhi, 1962, 137.

7. Raghuvansa, xi 3236,52, 117, 120.

8. Laxman Jha. Mithila still Rise, P-13 as quoted by Upendra Thakur, History of Mithila, Darbhanga, 1956, 87.

9. Mahabharata, Neelkanta ke Tika Sanhita, Poona, 199233, 12, 9.4 .

10. Sinha BP. (ed), The Comprehensive History of Biharm Vol, I, Part, II Patna, 1974, 61-62.

11. Ibid

12. Upendra op. cit, 10.

13. Sinha NP. Op. cit., 298.

14. Ibid, Part II, 269.

15. Misra denoting a mixed knowledge of scriptures.

16. Ram Prakash Sharma, Kameshwar Singh Sanskrit, Darbhanga, 2002, 9.

17. Anantlal Thakur. Comprehensive History of Bihar, Patna, I(I):49-52. 